\title{
SPOROPHYTES OF THE RARE LIVERWORT CEPHALOZIA MACOUNII
}

\author{
SANNA LAAKA-LINDBERG ${ }^{1} \&$ KIMMO SYRJÄNEN
}

\begin{abstract}
The dioicous epixylic liverwort Cephalozia macounii (Aust.) Aust. is rare over its entire distribution area in the Northern Hemisphere. It is protected under the EU Habitats Directive and classified as critically endangered in Finland and Sweden. One reason cited for its rareness and the declining trend in its distribution its poor reproductive capacity. It does not produce asexual gemmae, which in general is common among liverworts. Although female plants with perianths are quite common, the male plants of the species have rarely been seen and sporophytes have not been described until now. In this paper we describe and illustrate the sporophytes of C. macounii on the basis of an old specimen collected in Southern Finland in the 1800s.
\end{abstract}

Key words: Cephalozia macounii, sporophyte, spores, rareness, EU Habitats Directive

Sanna Laaka-Lindberg, Finnish Natural History Museum, Botany unit, P.O.Box 7, FI-00014 University of Helsinki, Finland; e-mail: sanna.laaka-lindberg@helsinki.fi

Kimmo Syrjänen, Finnish Environment Institute, P.O.Box 140,FI-00251 Helsinki, Finland; e-mail: kimmo.syrjanen@ymparisto.fi

\section{INTRODUCTION}

The epixylic liverwort Cephalozia macounii (Aust.) Aust. has a wide but sporadic distribution in the Northern Hemisphere taiga zone (e.g., Schuster 1974). It is considered rare over its entire distribution area. This species is also protected under the Berne Convention and listed in Annex II of the EU Habitats Directive. It has been classified as critically endangered (CR, Anonymous 2012) in Finland (Rassi et al. 2010) and Sweden (Anonymous 2010). It is red-listed as vulnerable (VU) in Europe (Anonymous 1995), but Schuster (1974) stated before red-listing of bryophytes began that the species may have declined as a consequence of habitat changes caused by human activities. A recent phylogenetic study including the genus Cephalozia revealed that this genus needs to be divided into two genera (Vilnet et al. 2012). Cephalozia macounii was kept in the type genus and therefore needed no nomenclatural change.

Cephalozia macounii grows on decaying wood, mainly on trunks in late stages of decay, as tiny homogenous patches or as single shoots among other bryophytes. It prefers often slightly paludi-

\footnotetext{
1 Corresponding author
}

fied old-growth conifer forest with an intact decay continuum of coarse woody debris and humid microclimate (e.g., Damsholt 2002; Laaka-Lindberg 2009; Hallingbäck 2010). Habitat loss is mainly due to forestry; for instance, most of southern Finland is covered by commercial forests with almost no suitable localities for old-growth forest specialists. The basic reason for its rareness and declining trend in its distribution is its poor reproductive ability (e.g., Laaka-Lindberg 2009). It is dioicous and does not produce asexual gemmae (Schuster 1974; Damsholt 2002). Female shoots with perianths have been found occasionally, but male plants have been found only recently in old specimens (see Plate 189 in Damsholt 2002). Sporophytes have been unknown until now (e.g., Schuster 1974; Paton 1999; Damsholt 2002). For this study, two digitalized type specimens of C. macounii available in JSTOR F0000068C from $\mathrm{F}$ and MICH514797 from MICH herbaria (see http://plants.jstor.org/search?plantName $=\% 22 \mathrm{Ce}$ phalozia + macounii\%22\&syn=1) were seen, and indeed, no sporophytes were present in them.

For compilation of the updated Finnish red list (Rassi et al. 2010) the herbarium materials in 
Finnish herbaria were checked through and the second author found a specimen in the H-SOL collection with sporophytes of C. macounii. Sextus O. Lindberg, who obviously identified the specimen collected by Emil F. Lackström, had likely seen the type specimen of C. macounii (Hep. Bor. Amer. Exsic. ined., No. 55; see protologue, Austin 1870), as he wrote it as a note on the back of the envelope. However, no particular note on the presence of sporophytes was marked. Here we describe and illustrate the sporophyte with spores and elaters of the species.

\section{MATERIAL AND METHODS}

A specimen of Cephalozia macounii collected by E. F. Lackström in southern Finland, Etelä-Savo Province, in Suomäki in Kangasniemi Parish in July 1874 (specimen H-SOL 2176001) was studied. Cephalozia macounii was growing on decaying wood ("ad ligna putrida"), and male and female shoots with sporophytes were present.

The structural features of the sporophytes were measured and photographed, and dissections of the sporophyte structures were studied under a light microscope mainly at $400 \times$. The associated species in the specimen were listed. It is somewhat problematic to identify all shoots of intermingled Cephalozia species, but fortunately C. macounii is rather easy to detect under a microscope. The density of $C$. macounii shoots in the patch was measured at $40 \times$ in 3 randomly picked $1 \mathrm{~mm}^{2}$ squares on the specimen. A Leica DSC280 microscope with a digital camera was used for photographing the microslides of opened sporophytes, spores and elaters. For size measurement the spores were kept in distilled water for $\mathrm{ca} 5$ hours and spore diameter was calculated as the mean of 10 spores in a randomly picked field; the longest diameter was measured with a micrometer at $1000 \times$. The spores were mostly attached to sporophyte structures (see Fig. 1). Note that the photographed spores (Fig. 2) are not the ones used for diameter measurements.

\section{RESULTS AND DISCUSSION}

Specimen H-SOL 2176001 contains a mixture of liverwort species with Cephalozia macounii. The size of the specimen is $\mathrm{ca} 4 \mathrm{~cm}^{2}$. Shoot density on the patch is on average $30 / \mathrm{mm}^{2}(\mathrm{n}=3)$. The measured frequency of shoot modes is shown in
Table 1 . On average $73 \%$ of the shoots are sterile, $4 \%$ males and $23 \%$ females. Not all female shoots bear a sporophyte but $47 \%$ do. The rarity of male shoots is noticeable even in this fertile patch, probably explaining the observed overall rarity of sexual reproduction in this species. No sporophytes were present in the specimen used for illustration by Damsholt (2002; Sweden, Härjedalen, Hede, leg. J. Persson, 1911). Both sexes obviously were present in that specimen. It has generally been considered that the sperm dispersal range of most bryophytes is short, on a scale of centimeters or even only millimeters, depending also on plant size (e.g., Crum 2001). It is not clear whether the male and female plants of C. macounii were close to each other in the specimen cited by Damsholt (2002). The presence of both sexes does not ensure sexual reproduction if the distance between them is too long or the occurrence of both sexes together is very rare.

Specimen H-SOL collected by E. F. Lackström was dated at the end of July, and practically all the $C$. macounii sporophytes present were open (Fig. 1). This suggests spore maturation in mid to late summer in southern Finland. Spores were found attached to capsule sectors and seta (Fig. 2), as were also the few elaters found (Fig. 3). The length of the mature seta is $2-3(-4) \mathrm{mm}$, and the oval capsule is $c a 740 \mu \mathrm{m}$ long and $320 \mu \mathrm{m}$ wide (Fig. 1). The cells of the capsule valves are rectangular, (14-)15-17 $\mu \mathrm{m}$ long, 3-4 times the width, with rather clear zigzag thickenings. The seta consists of 4 medullary cells surrounded by 8 cortical cells, as is characteristic for the genus Cephalozia

Table 1. Frequency of sexual modes of shoots measured on specimen H-SOL 2176001 of Cephalozia macounii (Aust.) Aust. Actual number of sterile shoots, males and females without sporophytes but with perianths and females with sporophytes in 3 randomly picked $1 \mathrm{~mm}^{2}$ squares on the specimen.

\begin{tabular}{c|c|c|c|c}
\hline $\begin{array}{c}\text { Sample/ } \\
\text { sexual mode }\end{array}$ & $\begin{array}{c}\text { Sterile } \\
\text { shoots }\end{array}$ & Males & $\begin{array}{c}\text { Females } \\
\text { with } \\
\text { perianths }\end{array}$ & $\begin{array}{c}\text { Females } \\
\text { with } \\
\text { sporophytes }\end{array}$ \\
\hline 1 & 13 & 1 & 2 & 2 \\
2 & 35 & 3 & 6 & 8 \\
3 & 17 & 0 & 2 & 1 \\
Mean & 22 & 1.3 & 3.3 & 3.7 \\
\hline
\end{tabular}




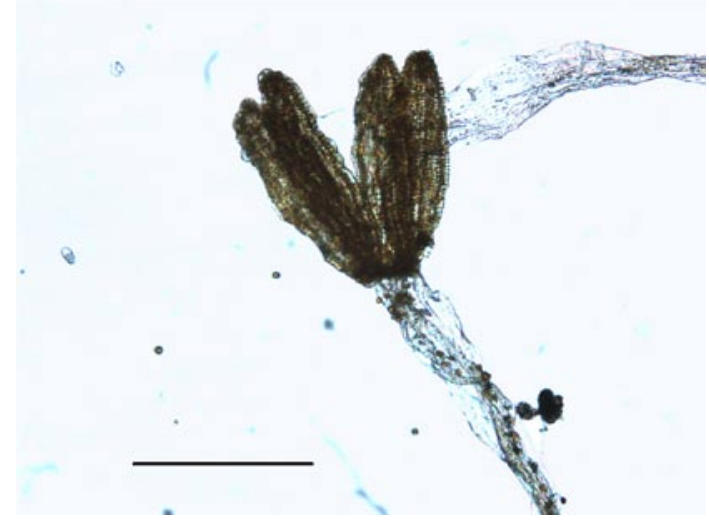

Fig. 1. Photograph of opened sporophyte of Cephalozia macounii (Aust.) Aust. Scale bar $=1 \mathrm{~mm}$.

(e.g., Schuster 1974). In this specimen the seta structure was somewhat difficult to see, however, since the setae were all flattened and partly decomposed. The overall sporophyte characteristics are similar to those in its close relative $C$. leucantha Spruce (e.g., Damsholt 2002), including the shape and size of the spores.

The spores of C. macounii are globular, (reddish) brown, with a slightly verrucose surface, and diameter of $c a 10 \mu \mathrm{m}$, ranging from 8 to $11 \mu \mathrm{m}$ (Fig. 2). The elaters are laxly bi-spiral, 8-11 $\mu \mathrm{m}$ wide and $60 \mu \mathrm{m}$ long (Fig. 3). The small size of the spores is often considered an advantage in long-distance dispersal (e.g., van Zanten \& Pocs 1981). On the other hand, small spores may face

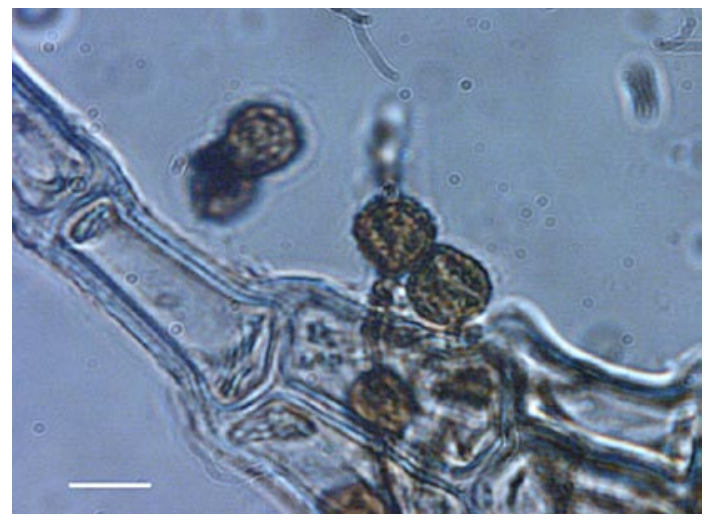

Fig. 2. Photograph of spores of Cephalozia macounii (Aust.) Aust. Scale bar $=10 \mu \mathrm{m}$. hazards in the germination phase, which reduces the reproductive benefit of easily dispersed spores. Most likely, however, the infrequency of spore production is more important in determining the rarity of $C$. macounii than dispersal ability as such.

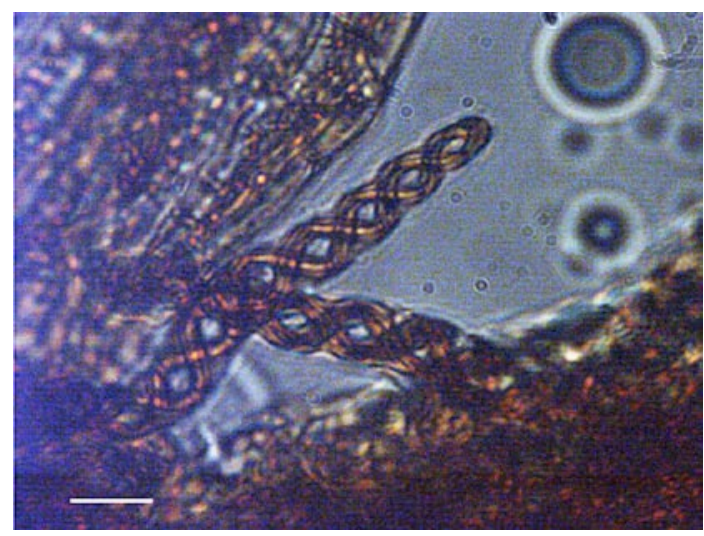

Fig. 3. Photograph of elaters of Cephalozia macounii (Aust.) Aust. Scale bar $=10 \mu \mathrm{m}$.

The small specimen studied also included other liverwort specialists of decaying wood which are now red-listed in Finland, such as Cephalozia catenulata (Huebener) Lindb. Anastrophyllum hellerianum (Nees ex Lindenb.) R. M.Schust., Calypogeia suecica (Arnell \& J. Perss.) Müll. Frib. and Lophozia ascendens (Warnst.) R. M. Schust. Most of these red-listed species seem to have a limited capacity to colonize isolated patches of old-growth forests in the heavily managed forest landscape of southern Finland, even though most of them produce both capsules and gemmae unlike C. macounii.

ACKNOWLEDGEMENTS. We thank the staff of the Finnish Natural History Museum LUOMUS for the loan of the specimen, and facilities for photography. We also thank the Finnish Environment Institute bryophyte conservation group for assigning us to look for old herbarium records of rare liverworts in Finnish herbaria. SLL warmly thanks Professor Timo Koponen for help with the old handwriting on the label of the H-SOL specimen and for valuable information on the older literature related to the study, and Lammi Biological Station, University of Helsinki, for work facilities and the use of a digital microscopy camera. 


\section{REFERENCES}

ANONYMOUS 1995. Red Data List of European Bryophytes. [April 2013]. http://www.bio.ntnu.no/users/soder/ECCB/ RDBTaxon.php.

ANONYMOUS 2010. Cephalozia macounii. In: ARTDATABANKEN, Swedish Redlist [April 2013]. http://www.slu.se/en/ collaborative-centres-and-projects/artdatabanken/the-redlist.

ANONYMOUS 2012. The IUCN Red List of Threatened Species. Version 2012.2. [April 2013]. http://www.iucnredlist.org.

AUSTIN C. F. ['1869'] 1870. Characters of some new Hepatica; (mostly North American), together with notes on a few imperfectly described species. Proc. Acad. Nat. Sci. Philadelphia 21: 218-234.

CRUM H. 2001. Structural Diversity of Bryophytes. The University of Michigan Herbarium, Ann Arbor.

DAMSHOLT K. 2002. Illustrated flora of Nordic liverworts and hornworts. Nordisk Bryological Society, Lund.

HallingBäCK T. 2010. Cephalozia macounii. In: ArtDatabanken. Swedish Species Information Centre. [April 2013]. http://www.artfakta.se/Artfaktablad/Cephalozia_Macounii_293.pdf.
LAAKA-LindBerG S. 2009. Cephalozia macounii - erittäin uhanalainen. In: S. LAAKA-LINDBERG, S. ANTTILA \& K. SYRJÄNEN (eds), Suomen uhanalaiset sammalet, pp. 68-70. Ympäristöopas S. Suomen ympäristökeskus, Helsinki.

PATON J. A. 1999. The liverwort flora of the British Isles. Harley Books, Colchester.

RASSI P., HYVÄRINEN E., JuSLÉN A. \& MANNERKOSKI I. (eds) 2010. Suomen lajien uhanalaisuus - Punainen kirja 2010. The 2010 Red List of Finnish Species. Ympäristöministeriö ja Suomen ympäristökeskus, Helsinki.

SCHUSTER R. M. 1974. The Hepaticae and Anthocerotae of North America East of the Hundredth Meridian. 3. Columbia University Press. New York - London.

Vilnet A. A., Konstantinova N. A. \& Troitsky A. V. 2012. Molecular phylogeny and systematics of the suborder Cephaloziinae with special attention to the family Cephaloziaceae s.l. (Jungermanniales, Marchantiophyta). Arctoa 21: 113-132.

ZANTEN B. O. VAN \& PóCs T. 1981. Distribution and dispersal of bryophytes. Advances Bryol. 1: 479-562. 